\title{
THE EFFECT OF PASTEURIZING TEMPERATURES ON THE PARATYPHOID GROUP
}

\author{
EDITH M. TWIS \\ From the Department of Hygiene and Bacteriology, University of Chicago
}

Work on the thermal death point of micro-organisms in milk has been carefully reviewed, the difficulties of the problem stated, and the possible sources of error pointed out by M. J. Rosenau, ${ }^{1}$ who investigated the thermal death point of a number of pathogenic microorganisms. He concluded that milk heated to $60 \mathrm{C}$. and maintained there for 20 minutes may be considered safe so far as conveying infections with the micro-organisms tested is concerned. These results were later confirmed by Schorer and Rosenau, ${ }^{2}$ using methods of actual pasteurization; the micro-organisms studied did not include B. paratyphosus A or B.

The first work on paratyphoid bacilli was by Bernhard Fischer in $1903 .^{3}$ It was mainly epidemiologic, but he makes the statement that he established by oft repeated experiment that the paratyphoid bacilli isolated in the epidemic studied were not killed by exposure to $60 \mathrm{C}$. for 30 minutes, that in two experiments bacilli were still living after exposure at $70 \mathrm{C}$. for from 10 to 25 minutes. Five minutes at $75 \mathrm{C}$. killed most of the organisms, but a few were living even then. The methods of experiment employed are not given in the report.

Friedel, Kutscher and Meinicke, ${ }^{4}$ working in Koch's laboratory, reported all paratyphoid bacilli killed by 5 minutes' exposure to $58 \mathrm{C}$.

EXPER. 1

The strains of bacilli used in this and in the following experiments are given in table 1. Their sources can be found in Jordan's article on the differentiation of this group." Whole milk was used and sterilized in the autoclave for 10 minutes at $10 \mathrm{lbs}$. pressure. The milk used in Chicago was certified milk. In Topeka, where certified milk cannot be obtained, the milk came from a dairy where the milk count rarely exceeds 100,000 per c c.

The milk was sterilized in $100 \mathrm{cc}$ lots in $150 \mathrm{cc}$ Erlenmeyer flasks; 0.1 c c of a 24-hour broth culture of the strain to be tested was introduced with

Received for publication Sept. 17, 1919.

1 Bull, 42, U. S. Public Health Service, 1908.

a Jour. Med. Research, 1912, 26, p. 127.

8 Festschrift, R. Koch, 1903, p. 271.

4 Klin. Jahrb., 1904-5, 13, p. 324.

J Jour. Infect. Dis., 1917, 29, p. 457. 
a sterile pipet which was left in the flask and used for stirring and for withdrawing the milk for plating. Before pasteurization, the milk was thoroughly stirred and $1 \mathrm{cc}$ portions withdrawn and plated in duplicate. The counts of these plates showed that the numbers of bacteria introduced in $0.1 \mathrm{cc}$ of a 24-hour broth culture were consistently in the millions.

TABLE 1

Strains of Bacilli Used in Experiments

\begin{tabular}{|c|c|c|c|c|c|c|c|c|c|c|c|c|}
\hline \multicolumn{5}{|c|}{$\begin{array}{l}\text { B. paratyphosus } B \\
\text { (26 strains) }\end{array}$} & \multicolumn{3}{|c|}{$\begin{array}{l}\text { B. paratyphosus A } \\
\text { (15 strains) }\end{array}$} & $\frac{\begin{array}{c}\text { B. typhosus } \\
\text { (6 strains) }\end{array}}{\text { Hopkins }}$ & \multicolumn{2}{|c|}{$\begin{array}{l}\text { B. enteritidis } \\
\text { (10 strains) }\end{array}$} & \multicolumn{2}{|c|}{$\begin{array}{l}\text { B. suipestifer } \\
\text { (10 strains) }\end{array}$} \\
\hline $\begin{array}{r}5 \\
8 \\
12 \\
47 \\
62\end{array}$ & $\begin{array}{l}115 \\
149 \\
150 \\
151 \\
152\end{array}$ & $\begin{array}{l}161 \\
169 \\
175 \\
179 \\
180\end{array}$ & $\begin{array}{l}185 \\
202 \\
211 \\
222 \\
223\end{array}$ & $\begin{array}{l}224 \\
240 \\
245 \\
250 \\
251\end{array}$ & $\begin{array}{r}3 \\
4 \\
9 \\
40 \\
42\end{array}$ & $\begin{array}{r}48 \\
138 \\
158 \\
188 \\
198\end{array}$ & $\begin{array}{l}215 \\
219 \\
229 \\
230 \\
231\end{array}$ & \begin{tabular}{|c|} 
Hopkins \\
189 \\
190 \\
197 \\
247 \\
607
\end{tabular} & $\begin{array}{r}50 \\
51 \\
52 \\
58 \\
204\end{array}$ & $\begin{array}{l}205 \\
206 \\
207 \\
226 \\
228\end{array}$ & $\begin{array}{r}63 \\
66 \\
116 \\
136 \\
166\end{array}$ & $\begin{array}{l}162 \\
163 \\
167 \\
173 \\
227\end{array}$ \\
\hline
\end{tabular}

Pasteurization was carried on in a water-bath set in a second bath so that the temperature could be carefully regulated. Thermometers were kept in the inner and outer bath and in the milk, and the temperature of the milk during the experiments did not vary more than $0.5 \mathrm{C}$. and usually less than $0.1 \mathrm{C}$. The flasks were set deep enough in the water so that the water came up on the outside of the flask to at least twice the depth of the milk inside. The greatest care was taken in moving the flasks, and in stirring and withdrawing the milk, to avoid getting any drops on the sides of the flask above the general level of the milk. At regular intervals, $1 \mathrm{cc}$ portions were withdrawn and plated in duplicate. The plates were incubated at $371 / 2 \mathrm{C}$. and counted after 24 hours, with a second count at 48 hours, when the colonies were very small and few.

The results of 12 strains of $B$. paratyphosus $B$ tested in this way were: 3 strains showed no growth after the temperature reached $60 \mathrm{C}$., 2 strains showed no growth after 1 minute at $60 \mathrm{C}$., 4 strains showed no growth after 3 minutes at $60 \mathrm{C}$., 3 strains showed growth after 3 minutes at $60 \mathrm{C}$.

As has been noted by other investigators of the thermal deathpoint of micro-organisms in milk, the organisms decrease very rapidly as the temperature approaches $60 \mathrm{C}$. The test of one strain is given in table 2 as an illustration.

TABLE 2

B. PARATYPHOSUS $B$ No, 224

Mili at 25 C. Immersed in Bath at $60 \mathrm{C}$.

\begin{tabular}{c|c|c}
\hline \hline $\begin{array}{c}\text { Time after } \\
\text { Immersion }\end{array}$ & $\begin{array}{c}\text { Temperature, } \\
\text { C. }\end{array}$ & $\begin{array}{c}\text { Number of Colonies } \\
\text { per c c }\end{array}$ \\
\hline At start & 25 & $0,900,000$ \\
4 minutes & 55 & 1,600 \\
8 minutes & 59 & 154 \\
12 minutes & 60 & 9 \\
13 minutes & 1 minute at 60 \\
14 minutes & 2 minutes at 60 & 1 \\
15 minutes & 3 minutes at 60 & 0 \\
16 minutes & 4 minutes at 60 & 0 \\
\hline
\end{tabular}


Different strains vary considerably in their resistance to heat. In most cases the milk reached $60 \mathrm{C}$. in from 10-12 minutes, but in two tests there was greater variation, and the results in these (table 3 ) seem to indicate that the difference in strains is, of the two, the factor of greater importance.

TABLE 3

Results of TESTS

\begin{tabular}{|c|c|}
\hline Time to Reach & $\begin{array}{l}\text { Time at Which No More Growth } \\
\text { Was Observed }\end{array}$ \\
\hline $\begin{array}{l}7 \text { minutes } \\
14 \text { minutes }\end{array}$ & $\begin{array}{l}1 \text { minute at } 60 \mathrm{C} \text {. } \\
3 \text { minutes at } 60 \mathrm{C} \text {. }\end{array}$ \\
\hline
\end{tabular}

As the numbers are greatly reduced, it becomes more and more possible that the one or two surviving may not be included in the $\mathrm{cc}$ withdrawn to plate. For testing this possibility by allowing the few surviving to multiply to the point where their detection would be easy the following experiment was added:

At the close of the pasteurizing period, the flask was set first in cold water and then in the ice-box to duplicate the cooling of practical pasteurization. After cooling, it was incubated at $371 / 2$ for 24 hours, a loopful transferred to a tube of broth and this in turn incubated at $371 / 2$ C. From the broth a stab was made in a Russell double sugar slant. Typical growth on these slants showed survival at temperatures at which negative plates had been secured, and this method was accordingly used with a number of strains. To check results with those of investigators who used other methods, B. typhosus (Hopkins) was run in parallel experiments. Several strains of paratyphosus B were also tried in this way without repeating the plating. In these cases $0.1 \mathrm{c} c$ of a 24-hour broth culture was introduced into $100 \mathrm{c} \mathrm{c}$ of milk. After stirring with a sterile pipet, a few drops were withdrawn into a broth tube and incubated. These served as checks on the presence of actively growing organisms at the beginning of pasteurization. The flask of milk was then put in the bath and treated like the others.

From one of these flasks B. typhosus was recovered after the milk had been held at $60 \mathrm{C}$. for 20 minutes. In order to be sure that this difference from the results obtained by Rosenau was not due to errors of technic in the method employed, I determined to test again the strains that had survived more than 3 minutes' exposure to $60 \mathrm{C}$., using Rosenau's method. 


\section{EXPER. 2}

Accordingly, thin-walled tubes with approximately $10 \mathrm{cc}$ of milk were substituted for $100 \mathrm{cc}$ in flasks. Whole milk was used, sterilized as before, but the tube was always well shaken before the introduction of bacteria to break the cream layer. The tubes were open during pasteurization, but the plugs were flamed and replaced when the tubes were taken from the bath. The room temperature and the time taken to raise the temperature of the milk to $60 \mathrm{C}$. were always recorded. Neither varied much. The room temperature at Chicago (summer months) was from $26 \mathrm{C}$. to $31 \mathrm{C}$; ; at Topeka (winter months), $22 \mathrm{C}$. or $23 \mathrm{C}$. The time taken to reach $60 \mathrm{C}$. was from 6 to 8 minutes.

Loopfuls were withdrawn into broth, in the greater number of cases at frequent intervals, but toward the end only twice-at from $58 \mathrm{C}$. to $60 \mathrm{C}$. and just at the close of pasteurization. Stabs from these broth tubes into Russell slants confirmed Rosenau's results. In approximately 35 tests of strains of B. paratyphosus B and 40 of parallel tests of B. typhosus (Hopkins) only one strain, of B. paratyphosus B, showed growth after exposure to $60 \mathrm{C}$. for 2 minutes.

These same tubes, from which loopfuls had been transferred to broth, were cooled and incubated at the close of pasteurization, and stabs made from them directly into Russell slants. Although the loopfuls removed to broth had failed, in every case except one, to indicate the presence of living bacilli after the temperature of the milk had been held at $60 \mathrm{C}$. for 2 minutes, after 24 hours' incubation of this same milk, the much smaller amount removed by a straight needle carried over into Russell slants bacilli which produced the effects of vigorous growth. Two strains of paratyphosus $B$ were recovered from milk that had been held at $60 \mathrm{C}$. for 30 minutes. Their identity was confirmed by agglutination with immune serum. It is clear that results obtained by plating $1 \mathrm{cc}$ of milk from 100 , or transferring one loopful into broth, cannot be taken as proof of the death of all the organisms in the sample. It is possible that we have here, not only the difficulty of catching one or two organisms in a comparatively large sample, but also some such stunning of the organisms as occurs in the case of B. coli in chlorinated water, ${ }^{6}$ though it is difficult to see why the organisms should not recover as well in broth and agar as in milk.

Tests were then made with a larger number of strains of $B$. paratyphosus $B$ and B. typhosus and strains of B. paratyphosus A, B. enteritidis and B. suipestifer. The withdrawal of any portion of the milk to broth was omitted, but stabs were made into Russell slants before pasteurization, and strains in which these controls did not show active growth were discarded.

A summary of all results obtained from milk which was heated to $60 \mathrm{C}$., held at $60 \mathrm{C}$. for a definite time, cooled and incubated is contained in tables 4 and 5 .

When one strain was tested a number of times, there appeared to be a time of exposure to $60 \mathrm{C}$. when the organisms sometimes died and in other experiments survived; a period just before the thermal death point. Such a period is seen in table 6 at from 15-20 minutes for B. typhosus Hopkins.

B H. E. Jordan cited by Race, Joseph, Chlorination of Water, 1918, p. 57. 
TABLE 4

Results of Tests

\begin{tabular}{|c|c|c|c|c|c|c|}
\hline \multirow{2}{*}{$\begin{array}{c}\text { Temperature } \\
\text { of Pas- } \\
\text { teurization, } \\
\text { C. }\end{array}$} & \multirow{2}{*}{$\begin{array}{l}\text { Time of } \\
\text { Exposure }\end{array}$} & \multicolumn{5}{|c|}{ Number of Strains Killed } \\
\hline & & $\begin{array}{l}\text { Paraty- } \\
\text { phosus B }\end{array}$ & $\begin{array}{l}\text { Paraty- } \\
\text { phosus A }\end{array}$ & $\begin{array}{l}\text { B. ty- } \\
\text { phosus }\end{array}$ & $\begin{array}{l}\text { B. enter- } \\
\text { itidis }\end{array}$ & $\begin{array}{l}\text { B. suipes- } \\
\text { tifer }\end{array}$ \\
\hline \multirow[t]{2}{*}{$\begin{array}{l}60 \\
60 \\
60 \\
60 \\
60 \\
60 \\
65\end{array}$} & $\begin{array}{r}3 \text { minutes } \\
5 \text { minutes } \\
10 \text { minutes } \\
20 \text { minutes } \\
25 \text { minutes } \\
30 \text { minutes } \\
30 \text { minutes }\end{array}$ & $\begin{array}{l}8 \\
3 \\
2 \\
1 \\
1 \\
1 \\
3 \\
2\end{array}$ & $\begin{array}{l}\because \\
\cdots \\
\cdots \\
\ddot{4} \\
4 \\
7\end{array}$ & $\begin{array}{l}\cdots \\
\cdots \\
\cdots \\
\ddot{2} \\
1 \\
4\end{array}$ & $\begin{array}{l}\cdots \\
\because \\
\because \\
\ddot{4} \\
\ddot{5}\end{array}$ & $\begin{array}{l}\ddot{ } \\
\ddot{*} \\
\ddot{8} \\
\ddot{2}\end{array}$ \\
\hline & & 20 & 15 & 7 & 9 & 10 \\
\hline
\end{tabular}

TABLE 5

Results of Tests

\begin{tabular}{|c|c|c|c|}
\hline \multirow[t]{2}{*}{ Organism } & \multirow{2}{*}{$\begin{array}{l}\text { Number } \\
\text { of Strains } \\
\text { Tested }\end{array}$} & \multicolumn{2}{|c|}{$\begin{array}{c}\text { Number of Strains Surviving } \\
30 \text { Minutes at }\end{array}$} \\
\hline & & $60 \mathrm{C}$ & $65 \mathrm{C}$ \\
\hline 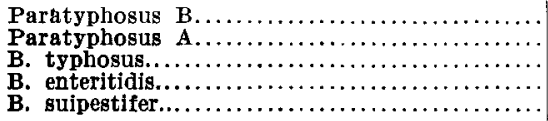 & $\begin{array}{r}20 \\
15 \\
7 \\
9 \\
10\end{array}$ & $\begin{array}{l}9 \\
7 \\
4 \\
5 \\
2\end{array}$ & $\begin{array}{l}6^{*} \\
0 \\
0 \\
0 \\
0\end{array}$ \\
\hline
\end{tabular}

* Confirmed by agglutination with immune serum.

TABLE 6

B. Typhosus (Hopkins)

\begin{tabular}{|c|c|c|}
\hline \multirow{2}{*}{ Exposure to $60 \mathrm{O}$. } & \multicolumn{2}{|c|}{ Russell Slants from Milk } \\
\hline & + & - \\
\hline $\begin{aligned} 5 & \text { minutes } \\
10 & \text { minutes } \\
15 & \text { minutes } \\
20 & \text { minutes } \\
25 & \text { minutes } \\
30 & \text { minutes }\end{aligned}$ & $\begin{array}{l}3 \text { times } \\
5 \text { times } \\
4 \text { times } \\
1 \text { time } \\
0 \text { times } \\
0 \text { times }\end{array}$ & $\begin{array}{c}\text { once (from flask) } \\
0 \text { times } \\
3 \text { times } \\
3 \text { times } \\
2 \text { times } \\
3 \text { times }\end{array}$ \\
\hline
\end{tabular}

The same point was brought out by the work of three students (Edith Conard, Mary Holl, Edna Smith) at Washburn College, who used these methods for determining the thermal death point of four strains of B. paratyphosus A. They recovered them after 25 minutes' exposure to $60 \mathrm{C}$., had varying results after from 30-34 minutes' exposure, and failed in at least two tests of each strain to recover any organisms after 35 minutes at $60 \mathrm{C}$.

This is somewhat in line with the results of the investigation of the death of $\mathrm{B}$. coli in pasteurized milk, ${ }^{7}$ though the variation there

7 Ayres and Johnson: Jour. Agric. Research. 1915, 3, p. 401. 
seemed very irregular, and was noticed in tests of such organisms as had survived the higher temperatures. In my experiments, the broth culture used to inoculate the milk was always a 24-hour growth from the agar slant previously used.

\section{SUMMARY}

Negative tests of comparatively small amounts of milk removed during pasteurization, or just at its close, cannot be taken as proof of the death of all organisms. When infected milk which had been heated to $60 \mathrm{C}$., held there for a definite time and then cooled, was incubated at $371 / 2 \mathrm{C}$., pathogenic organisms were recovered after exposures exceeding those of practical pasteurization. Of the strains of $\mathrm{B}$. paratyphosus $B$ tested, 6 were recovered from milk that had been held at $65 \mathrm{C}$. for 30 minutes, and 7 strains of B. paratyphosus A, 4 of B. typhosus, 5 of $\mathrm{B}$. enteritidis, and 2 of $\mathrm{B}$. suipestifer after 30 minutes at $60 \mathrm{C}$. It is possible that in a larger number of strains, some of even greater resistance might be found.

The greater number of organisms die out rapidly as the temperature approaches $60 \mathrm{C}$.

There is evidence that just before the exposure which kills all organisms, there is a period when survival is irregular, the few more resistant organisms sometimes living, in other tests dying. 